\title{
現代ヒンディー語作家の移動 —ビーシュム・サーヘニーとニルマル・ヴァルマー——
}

\section{鈴 木 美 和}

ビーシュム・サーヘニー（Bhīṣm Sāhnī, 1915～）とニルマル・ヴァルマー（Nirmal Varmā, 1929〜）は，ともにインド独立後のヒンディー文学を代表する作家の内に 数えられる．青年期の二人は左翼運動に夢を抱き，1950 年代前半のデリーで同じ 創作集団に参加した後，1950 年代後半より 1960 年代にかけて，当時の社会主義 国に暮らし翻訳活動に携わった。帰国後，サーヘニーは全国的な文学者団体であ る全インド進歩主義作家協会（All India Progressive Writers'Association）を代表する作 家となるが，対照的にヴァルマーは時に復古主義的な一面を持つ文化的ナショナ リストとも呼ばれる存在になる。このような彼らの位置の違いは，政治運動への 評価に加えて, 故国の文化やヒンディー語についての見解という点でも際立って 表れている。ここでは二人の間のそうした差異が, 移動の結果である長期の離郷 体験のなかで見出された個人的な関心と，ヒンディー語作家に対する要請とが重 なり合うとごろに生じていることについて考えたい".

現パーキスターン領パンジャーブの出身であるサーヘニーは, 1947 年の分離独 立に際し故郷喪失難民となりデリーに移住する. そして 1957 年から 1963 年まで, ソ連で発行される文献の公式な翻訳書の出版を担当したモスクワ外文出版 (Foreign Languages Publishing House, Moscow）に翻訳家として採用され，妻子とともにソ連で 生活した。ヴァルマーは 1959 年から 1968 年まで, プラハ東洋研究所 (Oriental Institute, Prague) とチェコスロヴァキア作家同盟（Union of Czechoslovak Writers）の招 聘によりチェコスロヴァキアに暮らし，チェコ語現代文学作品のヒンディー語へ の翻訳を行った，国境を越えて芸術家や文学者が移動するという事件は，強制さ れた移動と自主的な移動に大別されうるものだが，二人の翻訳家としての移動は 後者に含まれる特権的なものである．現時点では，強いられた移動のために帰郷 不可能な状態に陥るという体験はサーヘニーの側のみにある。しかしヴァルマー は内的な体験として, 文化的な意味では自分も一種の強制的移動を経た人間であ り，回帰困難な状態にあるという考えを表している. 
さて，彼らはほぼ同時期に社会主義国で暮らしたが，帰国後は社会主義と左翼 運動に対する見解に明白な相違が生じる.ヴァルマーはそれらをセキュラリズム と同様に外来の一要素ととらえ，条件付きで支持するという姿勢をしめすように なり，サーヘニーはコミュナルな暴力への抑止力として肯定的に評価し続ける. このような違いはインドにおける文化的同一性をめぐる見解にも表れる。彼らは ともに植民地化以前に遡る文化遺産の共有性を主張するが, ヴァルマーの場合は, それが西洋的な歷史観・時間認識と対峙するインドの文化的特質を提示するため のものであるのに対し，サーヘニーの場合は反コミュナリズムの動きを支える基 盤として主張されている. 二人がガーシディー（M.K.Gāndhī, 1869-1948）を支持す る理由も同様に異なり；ヴァルマーは反近代・反西洋の象徵として，サーヘニー は反コミュナリズムの象徵としての支持を表している.

分離独立直前に故郷で宗派間暴動が発生し, 難民となったサーヘニーは, コミュ ナル対立の拡大に対する危機感が強く，また独立後も州再編問題やパンジャーブ 紛争問題など,パンジャーブ出身のヒンディー語作家である彼のアイデンティティ に関る事件が続くなかで，常にコミュナリズム問題についての意見を求められて きた。これに対してヴァルマーは，ソ連主導の社会主義とチェコ事件により，そ れまでの理想を挫かれて帰国した後, 西洋世界に対するインドの独自性を追究し 始めたために,インド固有の文化に向けられる内外の関心をひきつける存在となっ ていった。このようにして，サーヘニーは分離独立，ヴァルマーはチェコ事件と いう別個の悲劇的な事件の証言者としての立場に置かれ, そこから一方は反コミュ ナリズム, 他方は近代西洋世界への批判という，二つの異なる動きを代弁すると いう状況に応じた主張を重ねてきたといえる。

彼らが抱く危機感や周囲から寄せられる関心の差異は, ヒンディー語をめぐる 見解にも表れる。ヴァルマーは，連邦公用語としてインドを代表するはずのヒン ディー語が英語の優勢によって軽視されていることを憂慮する。サーヘニーは, ヒンディー語の擁護運動が他のインド諸語話者からの反発を招いているという問 題点を指摘する.ヴァルマーが抱く言語についての関心は，彼に向けられる問い と同様に, 英語に対するヒンディー語の劣勢という問題にまつわることが多い. これに対して，パンジャービー語を母語とするサーヘニーは，インドに住む多言 語使用者としてのアイデンティティを自覚しながらヒンディー語で執筆を続けて おり,コミュナル対立への影響を考慮したうえで言語問題について発言している. 加えて重要な分岐点は, 人間が強制的に移動させられることについての考え方 
にあるといえる，ヴァルマーはそれを 20 世紀の歴史的災害とみなすが，サーへ ニーはかつてょり反復されてきたことであり，人間は順応することが可能である ととらえる。したがってそれに伴う文化的な交雑についても，サーヘニーはそれ を不可避のものとみなすが，ヴェルマーは特に西洋的なものがインドにもちこま れることには否定的である。この問題をめぐる差異は，インドにおける文化的同 一性についての見解の違いとつながっている.

サーヘニーとヴァルマーはこれまで, ともに作家の社会参加の必要性を認め, 連邦の公用語で書く作家として, 統一された故国の理想像と関ることを求められ るなかで個人的な選択を積み重ねてきた。その結果として，二人の間には前述の ようにさまざまな違いが生じたが, こうした隔たりは, 彼らの移動体験にまつわ る個人的な関心と，それに導かれた周囲からの期待の交点において形成されたも のであると考えることができる，そして今日，ヴァルマーはインドという名前を 伴って呼ばれる文化・民族の本来的な同一性を求める方向へ向かい, サーヘニー はそうした同一性の強制を警戒して, 特定の宗派と関連する文化伝統の称揚がコ ミュナリズムの蔓延を助長する危険を指摘し続けている.

1）ヴァルマーの作品と発言に関する記述は以下の文献に依拠する. Nirmal Varmā, D hal ān se utarte hue (Naī Dillĩ : Rājkamal Prakāśan, 1985) ; Dusre śabdõ mẽe（Naī Dillī : Bhārtīy Jñā npīthh, Lokoday Granthmālā 612,1997) ; Mere sākșātkār (Naī Dillī : Kitāb Ghar, Mere Sākṣātkār Sirīz, 1999) ; Ādi, ant aur ārambh（Naī Dillī : Rājkamal Prakāśan, 2001). サーヘニーについては以下 を典拠とする. Bhīṣm Sāhnī, Apnī bāt（Naī Dillī : Vāṇī Prakāśan, 1990）; Mere bhāì Balrāj （Naī Dillī : Neśnal Buk Ṭrasṭ, 1991) ; Mere sākșātkār (Naī Dillī : Kitāb Ghar, Mere Sākṣātkār Sirīz, 1996).

〈キーワード〉 ヒンディー文学, ビーシュム・サーヘニー, ニルマル・ヴァルマ (東京外国語大学大学院) 